\title{
RELIGIOUS TRADITIONS AND BELIEFS IN THE CULTURE OF DAGESTAN: HISTORY AND MODERNITY
}

\author{
(C) Sarat G. Hiyasova, Maida G. Mustafaeva, Elmira Sh. Musaeva
}

\author{
Dagestan State Pedagogical University, Makhachkala, Republic of Dagestan, \\ Russian Federation \\ science-almanac@mail.ru
}

\begin{abstract}
The article is devoted to an important and relevant topic of reflection of pagan customs and rituals in the traditional culture of Dagestan (using the example of traditional Islam). The authors set a goal to differentiate the purely religious-canonical and actually surviving, pagan forms in this religion. As a result of the analysis of a whole complex of pagan customs and rituals: a pilgrimage to the mountains, the cult of saints, graves, the cult of deceased ancestors, magic, and comparing them with the existing norms of Islam, it was found that pagan rudiments were firmly entrenched in folk, traditional Islam. It has been established that at the present stage, these vestiges and cults continue to influence the ethical and moral norms of the peoples of Dagestan, since they are often perceived as purely canonical norms of Islam. This circumstance is often caused by numerous disputes and discussions in modern society. The essence of the discussions usually boils down to the following. The religious concept of Islam clearly defines the thesis of rejection of any innovations in religion. As a rule, innovations or new teachings mean everything that was somehow superimposed on Islam over many centuries, and that has nothing to do with early Islam of the period of the righteous caliphs. Hence the question is whether this or that phenomenon in religion is a pagan relic, a rudiment, or this canonically justified view is of particular relevance.
\end{abstract}

Key words: culture, religion, rudiments, paganism, Islam, peoples of Dagestan, customs, traditions.

\section{[С.Г. Хиясова, М.Г. Мустафаева, Э.Ш. Мусаева Религиозные традиции и верования в культуре Дагестана: история и современность]}

Статья посвящена важной и актуальной теме отражения языческих обычаев и обрядов в традиционной культуре Дагестана (на примере традиционного ислама). Авторы поставили целью дифференцировать сугубо религиозно-канонические и собственно пережиточные, языческие форм в данной религии. В результате анализа целого комплекса языческих обычаев и обрядов: паломничество в горы, культ святых, могил, культ умерших предков, магия, и сопоставления их с существующими нормами ислама было установлено, что языческие рудименты прочно укрепились в народном, традиционном исламе. Установлено, что на современном этапе данные пережитки и культы продолжают оказывать влияние на этические, нравственные нормы народов Дагестана, так как зачастую воспринимаются как сугубо канонические нормы ислама. Этим обстоятельством зачастую вызваны многочисленные споры и дискуссии в современном обществе. Суть дискуссий как правило сводится к следующему. В религиозной концепции ислама четко обозначен тезис неприятия в религии каких-либо новшеств. Под новшествами или нововведениями понимается, как правило, все то, что так или иначе накладывалось на ислам на протяжении многих столетий, и что не имеет ничего общего с ранним исламом периода праведных халифов. Отсюда вопрос, является то или иное явление в религии языческим пережитком, рудиментом, либо это канонически оправданное воззрение имеет особую актуальность.

Ключевые слова: культура, религия, рудименты, язычество, ислам, народы Дагестана, обычаи, традиции.

Sarat G. Hiyasova - Ph.D. in Pedagogy, Associate Professor, Dagestan State Pedagogical University, Makhachkala, Republic of Dagestan, Russian Federation.

Maida G. Mustafaeva - Ph.D. (Advanced Doctorate) in Philosophy, Professor, Dagestan State Pedagogical University, Makhachkala, Republic of Dagestan, Russian Federation. 
Elmira Sh. Musaeva - Ph.D. in Philosophy, Associate Professor, Dagestan State Pedagogical University, Makhachkala, Republic of Dagestan, Russian Federation.

Хиясова Сарат Гасановна - кандидат педагогических наук, доцент, Дагестанский государственный педагогический университет, г. Махачкала, Республика Дагестан, Российская Федерация. Мустафраева Маида Ганифраевна - доктор философских наук, профессор, Дагестанский государственный педагогический университет, г. Махачкала, Республика Дагестан, Российская Федерация.

Мусаева Эльмира Шекералиевна - кандидат фрилософрских наук, доцент, Дагестанский государственный педагогический университет, г. Махачкала, Республика Дагестан, Российская Федерация.

In recent decades, due to cardinal changes in the life of post-Soviet society, interest in ancient ethnic history, art, and beliefs in the CIS countries, Russia and Dagestan, in particular, has increased. Problems covering various aspects of religion, including its influence on public consciousness, culture and life, not only have not lost their importance, but have recently become increasingly relevant.

Let's consider the issue of reflection of pagan rudiments in traditional Islam. In this case, it is not about isolated cases, examples, but about a whole complex of views and forms that have transformed from paganism into popular Islam. These forms are also present in Christianity, since it is known that the emergence of monotheistic religions was preceded by polytheism. Islam came out "with the intention to destroy even the most insignificant pagan customs, but folk traditions turned out to be stronger than this desire" [5, $p$. 65].

The pre-monotheistic ideas of the peoples of Dagestan do not stand alone, they, in many respects, coincide with the corresponding ideas of the peoples of the North Caucasus and Transcaucasia. An analysis of the pagan remnants of past centuries existing in the modern religious consciousness of ethnic groups can become an important source for the knowledge and analysis of the history, culture, and religion of the peoples of Dagestan and Kavkaz. These rudiments of paganism, one way or another, exerted and continue to influence the ethical, aesthetic, moral norms of modern peoples.

It should be noted that work on the study of the early forms of beliefs of the peoples of Dagestan has already been carried out. To one degree or another, this topic is reflected in the studies of V.M. Kotovich, S.Sh. Gadzhieva, A.G. Bulatova, A.O. Bulatova, N.A. Aglarova, S.A. Lugueva, B.I. Alimova, H.M. Khalilova, M.R. Khalidova, L.B. Gmyri and others. However, at the same time, the special literature practically does not touch upon the issues where religious norms rooted in paganism and the views of purely religious canonical are clearly distinguished.

So, soon after the birth of a new monotheistic religion, Islam, it began to spread in the territory of Dagestan. After the active introduction of Islam here, in Dagestan, in the $8^{\text {th }}$ $15^{\text {th }}$ centuries, paganism, it would seem, was already completely ousted from the worldview of the peoples of Dagestan, but this is not so. Traditional, or, as they say, popular, Islam has not supplanted the traditional beliefs and rituals that have evolved over the centuries with elements of pagan, surviving forms. Spreading across the Caucasus, Dagestan, traditional Islam adapted some of the local religious traditions and rituals and turned into a kind of symbiosis of Islam and paganism. It is important to emphasize that such processes were noted not only in Dagestan, but also everywhere, wherever the new religion penetrated. D.E. Eremeev noted that "spreading among the peoples of Asia and Africa, Islam has absorbed many local beliefs, customs, and holidays. In many countries, for example, the cult of saints and their graves appeared, which in itself contradicts early Islam, which rejected the worship of anyone other than the one and only God - Allah" [6, p.270]. 
On the territory of Dagestan, a huge number of graves revered by believers are also known. For example, believers in Dagestan, Azerbaijan, Chechnya and today make a pilgrimage to the mountains Shalbuzdag, Bakhargan, Chipir, Akhulgo, etc. This is based on dual faith, where primordially native, traditional elements of culture, i.e. paganism, played the role of the foundation in the formation of a new religion, and in many ways at that time it was the desire of the people themselves, who did not want to depart from the centuriesold traditions and customs. As for the norms and canons of religion, "the practice of canonizing saints is not accepted in Islam, and a real person or mythical hero becomes revered at the will of the masses" [8].

Here are some examples of the existing elements of the canonization of saints in Dagestan, which fundamentally diverge from the principles of Islam. So, for example, in the period of approximately $16^{\text {th }}-19^{\text {th }}$ centuries a significant place in the religious beliefs of the peoples of Dagestan, especially among the peoples of the Lezghin group, was occupied by the cult of local saints. They were numbered among the saints for all kinds of miracles attributed to them during their lifetime. In this cult, along with other surviving forms, elements of shamanism manifested themselves. So, for example, shamanic ideas are very vividly expressed in the legends about the saint Sheriff-Ali-Buba from the Lezghin village of Yaljug. Until recently, his feast (grave) was very popular and was attended by believers from Lezghin villages. They praise him during drought, childlessness, and various illnesses, they arranged prayers with dhikr at his grave. It was believed that this saint fulfills requests even after death. According to a legend, he lived in the first half of the $19^{\text {th }}$ century. He was considered a strange person: he could suddenly disappear and also suddenly appear. Davrush-gyazhi and Gapiz from the village of Richa showed the same ability for short-term overcoming of great distances. So, about the first, they said that once on the holiday of Ramadan, he disappeared from a group of men who were heading from the cemetery to the mosque, visited Mecca and was a little late for prayer at the mosque. Gapiz, also according to legend, allegedly in the presence of witnesses turned into a dove, flew to Mecca and also flew in. In addition to the gift of overcoming considerable distances, the saints were also credited with the gift of clairvoyance, healing, and healing. So, for example, according to legends, the holy sheikh Kurban from the Rutul village of Ikhrek also possessed the gift of clairvoyance. Once, a goat disappeared from one of the villagers. One of the residents, who stole a goat, began to accuse the innocent. Sheikh Kurban, who had ripened in time at that time, put his staff horizontally to the thief's stomach and from there the bleating of a goat was heard. The thief was exposed. It should be noted that this is a typical Shamanic trick based on ventriloquism. In general, according to legend, the staff is an indispensable property of many saints. Gapiz, also according to legend, allegedly in the presence of witnesses turned into a dove, flew to Mecca and also flew in. In addition to the gift of overcoming considerable distances, the saints were also credited with the gift of clairvoyance, healing, and healing. So, for example, according to legends, the holy sheikh Kurban from the Rutul village of Ikhrek also possessed the gift of clairvoyance. Once, a goat disappeared from one of the villagers. One of the residents, who stole a goat, began to accuse the innocent of this. Sheikh Kurban, who had ripened in time at that time, put his staff horizontally to the thief's stomach and from there the bleating of a goat was heard. The thief was exposed. It should be noted that this is a typical Shamanic trick based on ventriloquism. In general, according to legend, the staff is an indispensable property of many saints.

Sometimes it happened that some rudiments of pre-monotheistic ideas in some aspects coincided with the doctrine of Islam, or rather did not contradict it. In this case, the population of Dagestan perceived them as Sharia, Islamic views. In similar cases, they were introduced by the peoples of Dagestan into everyday life, accompanied by appeals to 
the Almighty, with the mention of the name of the Prophet Muhammad, other saints, with the reading of Muslim prayers, which further misled the people that the new of all these vestiges is Islam.

Within the framework of the foregoing, we believe that in this issue at the present stage, it is important not to identify the positive or negative of certain vestiges and rudiments, but to accept and study them, since this is an already established history and culture of the peoples of Dagestan, the Caucasus, which must be treated with respect and care. In this course, the analysis of the passed stage, its rethinking, is more relevant. It is important to think about it here, to learn certain lessons. It's another matter when today, in the 21st century, concepts are still being replaced, despite a number of fundamental studies of this problem, the analysis of which makes it possible to clearly distinguish between pre-monotheistic and proper Islamic norms. Let's dwell on some of them in more detail.

Relative forms of culture of the peoples of Dagestan include the cult of the deceased ancestors and the funeral rituals associated with it. Until now, in Dagestan, it is customary for a number of its peoples to call a child by the names of deceased relatives (grandfathers, grandmothers, uncles, etc.), for some of them, for example, among the Kumyks, this name is very even, even if it is the name is very dissonant.

In the funeral rituals of the Dagestan peoples, ideas about a certain impurity of the corpse have also been preserved. So, there are still survivals when some of the peoples of Dagestan, after the burial of the corpse, the walls of houses are whitewashed or coated with fresh clay, others are everywhere cleaning the dwelling, carpets, rugs, skins, wiping door and window openings with a damp cloth and etc. The things with which the deceased touched are thoroughly ventilated in the fresh air for at least three days. There are isolated cases when food from the room where a person died is thrown out. they think that everything in the room is splashed with blood, because according to the ancient belief, the Angel of Death Azrael cuts a man's throat, taking his soul. Cases are quite common when, on the contrary, the dwelling where the deceased was located is not cleaned, the floor is not swept for three days, i.e. do not tolerate dirty linen.

To this day, a number of the peoples of Dagestan do not turn off the light in the house of the deceased, so that the spirit of the deceased can visit his house without difficulty; it is also believed that in the light, the soul will not be able to harm the household. In the culture of Dagestan, the views have also been preserved, according to which the soul of the deceased in the first days after death comes home hungry, and it must be fed. Thus, treating loved ones, relatives who came for condolences, symbolically saturates the soul of the deceased person.

Probably, in order to calm down, alleviate the situation of the soul of the deceased from ancient times and to this day, it is customary for the peoples of Dagestan to read the Koran on the graves of the deceased, which in religion, Islam, in principle, does not in any way affect the position of the deceased in the other world, and also to single out the third, seventh, the fortieth (fifty-second) days of the memorial ritual, which researchers consider more as a "consolidating act of fastening the bonds of kinship and good-neighborliness" [8, p. 23], rather than an attribute of Islamic culture. Also, the ostentatious mourning of the deceased has nothing to do with the canons of Islam, the more condemned by this religion of self-torture when mourning the deceased type of beating on the knees, stomach, scratching the face, pulling out hair, which are still preserved in the traditional culture of the Kumyks, Dargins and other peoples of Dagestan. Among the Turkic-speaking peoples of Dagestan, men also mourned the deceased. So, for example, in our days, men from some regions of Dagestan enter the house of the deceased crying and groaning before and after burial. This is certainly not approved by the religion of Islam. On the contrary, here the pa- 
tient, even closer to the fatal, acceptance and transfer of loss by a person is welcomed, and only an unseen sadness, and sadness here does not cause condemnation.

Today, a huge number of remnants of culture have survived, often interpreted again as religious, the essence of which comes down directly to magic and magical rites. Especially many of them were reflected in the so-called children's rituals. It was believed that young children are most vulnerable to various diseases and ailments, while their causes were not seen at all in the medicine and physiology of the child. The main reasons boiled down to the actions of certain evil forces with which it was necessary to fight. A whole complex of objects, which basically carry an apotrepea, protective function, goes back here. These include popular to this day among the people beads from the "evil eye", some of which are sewn to clothes, pieces of quince wood, charcoal, fangs of animals (wolf, cabana), etc. Until now, among the Kumyks, Dargins and some other peoples of Dagestan, cereal-legume porridge is cooked when a child's first teeth are teething or because of his first steps. It is believed that cooking this porridge with its distribution to neighbors helps to facilitate this process. The peoples of Dagestan cooked a similar porridge in the early stages in the event of a long drought to call the long-awaited rain, and, what is especially interesting, it is cooked on the eve of the festive Islamic day of Ashura.

Everywhere among the peoples of Dagestan, echoes of imitative, initial magic, magic of color, magic of numbers, sympathetic magic has been preserved. To this day, the tradition is alive that to hold important events, such as a wedding, naming a child's name, putting him in a cradle, etc. preferably on certain days and months. For example, you cannot give a bride a single gift like one scarf, one ring. At the present stage, as well as in the past centuries, among a number of the peoples of Dagestan, they try to entrust the cutting of the first nails to a baby to a skilled person who is good at some crafts, labor skills, in order to transfer this skill to the child. Or they believe that it is highly advisable to throw the trash out of the house before the evening prayer. Moreover, as a rule, the bearers of all these rudiments are the adult generation of the Daghestani peoples, which identifies itself primarily with Muslims, but sees nothing wrong with the performance of pagan remnants, which it perceives as centuries-old traditions of ancestors.

Unfortunately, at the present stage, the methods of love or harmful magic have not lost their relevance. Therefore, in our days, the date of the conclusion of a Muslim marriage (magar) is being kept in strict secrecy, since they believe that this particular day is very favorable for various methods of harmful magic. Such as, for example, tying knots, when, tying invisible knots on the clothes of the newlyweds, they prevented the conclusion of an unwanted union; either practiced knotting to deprive men of their strength and destroy marriage unions; pulling out of the scabbard and putting a dagger in them, to opening and closing locks, etc. There are a lot of similar examples concerning magic. One gets the impression that of all the known remnants of paganism, much more echoes of magic have survived in Dagestan culture.

So, the study and analysis of the rudiments of pre-monotheistic beliefs in the life of modern society is still a topical issue today. Increasingly, there is an increased interest of the Dagestani peoples in their history and in the preceding religious forms. Analysis of the research on this issue showed that pagan forms and beliefs largely passed the local stage of formation and development. Our analysis of this topic allowed us to draw the following conclusions.

A significant factor in the system of the spiritual culture of Dagestan in general and in traditional Islam, in particular, continues to be rudimentary forms and cults, of course, in conjunction with other cultural and historical phenomena. At present, the influence of surviving forms of religion on the life of the peoples of Dagestan is as great as in the distant past. The peoples of Dagestan, as before, believe in "spoilage", "evil eye". Also relevant 
are funeral and memorial rites, the cult of ancestors, ideas about the soul of ancestors and their obligatory feeding, etc. Various forms and methods of magic, especially defensive (preventive) magic, are also present in the life of the Dagestani peoples. The early (pagan) religious forms and cults, traditional for the peoples of Dagestan, along with the dominant religion of Sunni Islam, continue to remain a significant factor in the system of spiritual culture, in conjunction with other cultural and historical phenomena and processes [9]. Popular Islam and traditional Islam did not eradicate the ancient ideas of the peoples, but in many ways even consolidated them.

\section{Лumepamypa}

1. Агларов М.А. Из верований народов Западного Дагестана. Проблемы мифологии и верований народов Дагестана. Махачкала, 1988. с. 70.

2. Басилов В.Н. Культ святых в исламе. М.: Мысль, 1970. 144 с.

3. Булатов А.О. Пережитки домонотеистических верований народов Дагестана в XIX начале XX века. Махачкала,1990. 265 с.

4. Гаджиев Г.А. Доисламские религиозные верования и обряды у народов Нагорного Дагестана в XIX-начале XX в. (Аварцы). Ф.3. Оп.3. Д.525.

5. Гольдциер И. Культ святых в исламе. М., 1938. с. 61

6. Еремеев Д.Е. Ислам: образ жизни и стиль мышления. М.: Политиздат, 1990. 288 c.

7. Культ святых в исламе. [Электронный ресурс] https://ru.Wikipedia.org/wik (дата обращения 28.03.16)

8. Лугуев С.А. Духовная культура народов Дагестана XVIII-XIX вв. Ф.5. Оп.1. Д.977.

9. Maida G. Mustafaeva, Elmira Sh. Musaeva, Zarema S. Mustafaeva. Various Problems of Educational Process in Multilingual Dagestan Under the Globalization Conditions: History and Modernity // Научный альманах стран Причерноморья. 2018. № 1 (13). C. 11-18.

\section{References}

1. Aglarov M.A. Iz verovaniy narodov Zapadnogo Dagestana. Problemy mifologii i verovaniy narodov Dagestana [From the beliefs of the peoples of Western Dagestan. Problems of mythology and beliefs of the peoples of Dagestan]. Makhachkala, 1988. p. 70 (in Russian).

2. Basilov V.N. Kult svyatykh v islame [The cult of saints in Islam]. Moscow: Mysl,1970. 144 p. (in Russian).

3. Bulatov A.O. Perezhitki domonoteisticheskikh verovaniy narodov Dagestana $v$ XIX nachale XX veka [Remnants of the pre-monotheistic beliefs of the peoples of Dagestan in the 19th and early 20th centuries.]. Makhachkala,1990. 265 p. (in Russian).

4. Gadzhiyev G.A. Doislamskiye religioznyye verovaniya i obryady u narodov Nagornogo Dagestana $\vee$ XIX-nachale XX v. (Avartsy) [Pre-Islamic religious beliefs and rituals among the peoples of Dagestan in the 19th and early 20th centuries. (Avars)]. Fund 3. List 3. Case 525 (in Russian).

5. Goldtsiyer I. Kult svyatykh v islame [The Cult of Saints in Islam]. Moscow, 1938. p. 61(in Russian).

6. Yeremeyev D. Ye. Islam: obraz zhizni i stil myshleniya [Islam: way of life and style of thinking]. Moscow: Politizdat, 1990. 288 p. (in Russian).

7. Kult svyatykh v islame. Available at: https://ru.Wikipedia.org/wik (accessed 28.03.16) (In Russian). 
8. Luguyev S.A. Dukhovnaya kultura narodov Dagestana XVIII-XIX vv. Fund 5. List 1. Case 977 (in Russian).

9. Maida G. Mustafaeva, Elmira Sh. Musaeva, Zarema S. Mustafaeva. Various Problems of Educational Process in Multilingual Dagestan Under the Globalization Conditions: History and Modernity. Science Almanac of Black Sea Region Countries. 2018. No. 1 (13). pp. 11-18. 